\title{
O problema da produção na ideologia contemporânea *
}

\author{
Migueli Reale \\ Catedrático de Filosofia do Direito \\ na Universidade de São Paulo - \\ Presidente do Instituto Brasileiro de \\ Filosofia.
}

Da economia de consumo à economia de produção

E para mim grande honra proferir a aula de encerramento dêste curso, realizado graças à colaboração da Federação das Indústrias do Estado de São Paulo com o Instituto Brasileiro de Filosofia.

Desejo, inicialmente, pôr em realce a preocupação dos homens de emprêsa pelos problemas teóricos relativos à produção econômica e às atividades mercantis. Essa preocupação doutrinária cresce dia a dia, o que é deveras louvável, pois, como advertiu um dos maiores economistas contemporâneos, JoHn Maynard Keynes, quando certos homens de negócios se declaram, ou se julgam isentos de influências teóricas, na realidade estão sendo governados, inadvertidamente, por idéias de algum economista defunto. São homens que, na rotina de sua existência produtiva, não fazem outra coisa senão traduzir idéias mortas há muito tempo. Mas os verdadeiros e autênticos homens de emprêsa sabem que é chegado o momento de fazer uma pausa em sua faina quotidiana, para a tomada de consciência de seus próprios problemas e a verificação do es-

(*) Conferência proferida no "Fôro Roberto Simonsen" segundo notas taquigráficas revistas e completadas pelo A.. 
tado atual do problema humano em face da economia e, o que não é a mesma coisa, da economia no complexo dos problemas do homem.

Quando escolhi o tema — "O problema da produção na ideologia contemporânea" — tinha por finalidade mostrar, sob vários aspectos e de vários ângulos, embora de modo sucinto, a importância fundamental que a produção econômica vem adquirindo na época moderna, sobretudo a partir do fim do século xvıII, da Revolução Francesa até aos nossos dias.

O assunto é de tamanha grandeza, de tal magnitude que seria impossível penetrar em sua essência sem perspectiva histórica. A análise dos antecedentes históricos impõe-se em qualquer indagação de natureza social, como todos o reconhecem, mas é indispensável também que o exame das chamadas causas remotas e próximas do "fato histórico" seja processado na totalidade de suas conexões de sentido, à luz da tábua de valores que distingue a estrutura de cada ciclo de civilização.

Volvendo os olhos para a vida dos povos ocidentais, há um século e meio, ou pouco mais do que isto, deparamonos com uma vida econômica dirigida por padrões e esquemas completamente distintos dos vigorantes em nossos dias. Desde a antiguidade clássica, desde o mundo grecoromano, passando pela época medieval, até meados da época moderna, podemos verificar que a economia se desenrola prevalecentemente em tôrno do problema do consumo. Produz-se para atender sobretudo a necessidades imediatas e rotineiras do homem, sendo a produção sempre bitolada e determinada por exigências prévias dos consumidores. De certa forma, podemos dizer que era o consumidor o agente da vida econômica, porque era no sentido de suas pretensões que giravam as expressões básicas da atividade produtiva, por mais diversos que pudessem ser os fins visados pelos produtores, empenhados no acréscimo de seu patrimônio, desde o puro prazer material da posse até à sua conversão em instrumento de 
domínio social e político. Dir-se-ia que as possibilidades do consumo, bem diminutas em relação ao padrão de vida do homem contemporâneo, traçavam prèviamente as possibilidades da produção.

No fim do século XvirI verificam-se, contudo, duas transformações fundamentais, uma no plano das idéias, notadamente no plano das idéias políticas; e outra no âmbito das realidades materiais: uma revolução, digamos assim, subjetiva, coincidente com outra de natureza objeliva.

A revolução subjetiva operou-se no sentido da afirmacão da plena liberdade humana na esfera da produção econômica, desvencilhando o produtor de todos os entraves de caráter moral, político ou jurídico que, bem ou mal, disciplinavam antes rìgidamente o "status" do "homo aeconomicus"

No chamado "Ancien Régime", ou seja, na estrutura política anterior à Revolução Francesa, tôda a economia, de uma forma ou de outra, encontrava-se subordinada a um complexo de leis e de regulamentos, em virtude dos quais o produtor só era concebido em certa situação jurídica, como elemento pertencente a um dado quadro social de natureza corporativa, grupalista ou geográfica. Com a Revolução Francesa, completa-se o reconhecimento do valor do indivíduo como indivíduo, e, concomitantemente, o poder da vontade criadora também no cenário econômico: era o momento marcante de um longo processo de emancipação, assinalando o rítmo novo da chamada cultura individualista "burguesa", pela transladação progressiva do fulcro diretor da sociedade das antigas instituições para o gênio inventivo empreendedor e absorvente de personalidades tangidas pela sêde do lucro e pelas vaidades da fortuna.

A mentalidade aventurosa e confiante, que já desprendera o homem do Renascimento de uma série de "limitações ideológicas", entreabrindo-lhe as vias da nova Ciência, da nova Arte e da nova Filosofia, repropondo em novos 
têrmos a problemática do Cristianismo, atinge $o$ seu "climax" com a declaração dos direitos da nova Economia. Estamos, pois, antes de mais nada, diante de um novo estado de espírito, de uma nova atitude perante os problemas humanos.

O homem passa, em suma, a valer por si só, como centro autônomo de interêsses econômicos, independentemente do seu enquadramento social, liberto, por conseguinte, de qualquer filiação de natureza corporativa ou, como se diz modernamente, de qualquer filiação sindical ou burocrática.

Ora, essa libertação do homem no sentido da afirmação de sua individualidade como ente criador de riquezas encontrou, ao mesmo tempo, uma situação objetiva propícia ao desdobrar-se da personalidade. Refiro-me ao aparecimento da máquina, pressuposto material de vertiginoso desenvolvimento industrial.

A era da economia industrial, como devem saber, desdobra-se em três momentos diferentes, discriminados em função dos tipos de maquinismos ou de energia neles aplicados. A sua primeira fase é governada pela utilização da máquina a vapor, graças à qual se transformaram os processos produtivos, sobretudo na Inglaterra, que desde logo se colocou à testa da avançada capitalista. A segunda época é determinada pelos motores de explosão e o emprêgo da eletricidade. Motor de explosão e eletricidade vieram alterar substancialmente o processo produtivo, provocando, em poucas décadas, um progresso de ordem material que teve como conseqüência imediata o robustecimento da crença iluminista no poder emancipador da ciência, especialmente das ciências positivas.

A terceira fase da era industrial sòmente agora se esboça, com a utilização da energia atômica, da energia nuclear, com efeitos surpreendentes e imprevisiveis.

Eis aí três fases distintas que demonstram o íntimo conúbio existente entre produção econômica e ciência, produção econômica e técnica. 
Êste é um ponto merecedor de nossa melhor atenção. Muda-se o sentido da ciência. Poderíamos dizer, louvandonos numa expressão feliz de André SiegFried, que a ciência deixou de ser ciência apolínea para ser ciência dionisíaca. Ou, por palavras, cessou o primado da especulação científica pura, para projetar-se, com dimensão dominante, a aplicação da ciência em sentido pragmático, a face utilitária da ciência.

$\mathrm{Na}$ antigüidade clássica é sabido que um Arquimedes, por exemplo, revelava certo escrúpulo, quando não apreensão, ao ver as suas descobertas envolvidas em aplicações de ordem prática. Pois bem, altera-se completamente, no decorrer do século passado, a mentalidade dos cientistas. A ciência quase que se converte em instrumento de produção, ou mais amplamente, em instrumento de vida, quando não se reduz a um cabedal de conhecimentos a serviço de interêsses momentâneos ou de paixões humanas. E por estar a ciência cada vez mais absorvida pela premência dos desejos humanos que se disse, com feliz aplicação de categorias do pensamento de NiETzscHE, que ela perdeu o seu esplendor apolíneo, a transparência cristalina da pesquisa pura, para receber o conteúdo dionisíaco da vida. É claro que focalizo, aqui, as linhas mais vivas do problema, pois não ignoro a importância das investigações desinteressadas, a busca da verdade em si mesma, da qual desabrocham, quando menos se espera, múltiplas e inesperadas aplicações utilitárias.

O certo é que a ciência procede cada vez mais jungida à técnica, até ao ponto de se poder afirmar que a técnica é a sombra da ciência, ou quase a ciência em têrmos de produtividade. Quando a ciência se projeta em formas de inversão pragmática, segundo dados de certeza e de garantia, temos o processo técnico como projeção natural da verdade científica.

Recapitulando, verifica-se que, na grande equação da revolução industrial, conjugaram-se um fator de ordem subjetiva, pela afirmação do poder criador do homem 
livre de peias normativas, e um fator objetivo, ligado ao aparecimento de condições materiais que propulsionaram e facilitaram as conquistas dos homens de emprêsa.

Outros fatôres poderiam ser aqui lembrados operando na história do capitalismo, como, por exemplo, o espírito religioso de fonte calvinista, e mais remotamente de inspiração protestante, chegando a colorir de significado transcendente a arte de enriquecer e produzir, visto como a fortuna traduziria um sinal de "eleição", uma graça de Deus, enquanto a pobreza passava a ser vista como marca de abandono, um sinal de privação da graça. Daí o ímpeto realizador, harmonizando-se a conquista terrena dos bens materiais com os desígnios celestiais, vivendo alguns econômicamente "sub specie aeternitatis", aceitando os sacrifícios da poupança e a dura vida diuturna de trabalho, não como pena, mas como forma de salvação. Lembraria, outrossim, as ordenações jurídicas modeladas segundo o individualismo romano, as reelaborações burocráticas do Estado Moderno, as mudanças radicais operadas nos conhecimentos geográficos e astronômicos, as novas concepções sôbre a arte da guerra, como têm sido assinalado pelos estudiosos da era capitalista, desde Weber a Sombart, mas, no fundo, tôdas as características apontadas redundariam no reconhecimento daquela dupla revolução operada, por intima e compreensível polaridade, no plano subjetivo dos valores espirituais e objetivada na criação dos correspondentes meios e instrumentos técnicos de ação.

O que importa, porém, observar, a esta altura da exposição, é que, sob o impacto dêsse complexo de fôrças, a economia perde, paulatinamente, o seu eixo primitivo, que era o consumo, quase estàticamente concebido, para passar a girar em tôrno de outro eixo fundamental, a produção, suscetivel de suscitar e revolucionar as exigências dos consumidores.

Se indagássemos de um mestre da escola clássica sôbre o fenômeno essencial da economia, a resposta provável seria no sentido de apresentar a produção como centro polarizador de todo o processo econômico. 
Se mais tarde aparece determinada corrente, aliás de ressonância limitada a círculos culturais brasileiros, afirmando ser a economia a ciência das trocas, tal assertiva, em última análise, em nada viria alterar os dados do problema, pois a produção ainda se coloca no centro da vida econômica, embora culminando na circulação das riquezas.

Na realidade, o capitalismo industrial é impelido pela preocupação da busca permanente e autônoma do lucro e, por conseguinte, tem como fulcro a idéia central de produzir livremente a fim de obter um resultado positivo suscetível de novas inversões, num crescendo de perfectibilidade técnica. Fiel a essa diretriz, o homem de emprêsa subordina tudo à finalidade lucrativa do empreendimento, no pressuposto ético de que não haveria melhor modo de contribuir para a prosperidade comum.

$\mathrm{O}$ início do capitalismo industrial, como todos o reconhecem, foi áspero e duro, pois se quis tirar da máquina o máximo de vantagens. Reduzir, de um lado, a participação da mão de obra e, de outro, substituir o trabalho dos adultos pelo das mulheres e das crianças, eis dois propósitos que animaram os primeiros organizadores de estabelecimentos maquinofatureiros, dando origem a um período dos mais negros da história econômica do Ocidente, só comparável ao tráfico do trabalho servil nas terras americanas.

É êsse o momento mais triste da história do capitalismo, no qual se quer obter da máquina todo o proveito possível, pela preocupação exclusiva da produção pelo menor custo com o máximo resultado. A máquina serviu, sobretudo. como instrumento de substituição do homem, o que explica tenha ganho foros de verdade científica uma estranha concepção da produção em têrmos quase materiais ou materialistas. Eu me refiro a certas teorias da escola liberal, no sentido, por exemplo, de que sòmente se poderia falar em produção no caso específico de manufatura de objetos materiais úteis. Quando vemos um ADAM Smith, um Ricardo ou um Stuart Mill, que são economis- 
tas clássicos, o terceiro já com certas tintás de revisionismo, cientistas penetrantes e objetivos, movidos sempre por espírito de análise desapaixonada, afirmar que o homem só produz quando gera algo de material, é que podemos sentir tôda a fôrça de uma tendência destinada a acentuar progressivamente a deshumanização da economia, ou, a "coisificação" da atividade produtiva. Dizia-se, por exemplo, que o sapateiro, ou seja, aquêle que faz sapatos, produz, mas o engraxate, aquêle que limpa sapatos, não realiza qualquer processo produtivo. Produzir equivale a criar "coisas". É claro que tal concepção foi logo alvo de críticas procedentes, que demonstraram o equívoco de ligar-se essencialmente a produção ao fabrico de bens corpóreos, porquanto, no fundo, o homem não cria de maneira absoluta, mas sempre transforma o existente, inovando em relação ao "processus" expontâneo da natureza.

Quem desloca qualquer bem de ordem econômica de um mercado para outro está criando algo, que é a nova dimensão de disponibilidade, de afetação utilitária ou ofelímica atribuída ao bem, em função de exigências humanas diversas e de outras possibilidades de consumo. Mister foi, pois, alargar-se o conceito de produção para que abrangesse, em sua compreensão, tôda atividade econômica geradora de bens materiais e imateriais suscetiveis de melhor atendimento às necessidades humanas, em função de variáveis ciclos de cultura.

Por mais que se alargasse o conceito de "produção", com o risco de abranger indiscriminadamente todos os aspectos da atividade econômica, nem por isto perdia ela a sua posição preeminente, quase que absorvente nos quadrantes da ciência econômica.

O consumo, um dos problemas fundamentais da economia antiga e medieval, e até mesmo das primeiras centúrias do capitalismo moderno, passou a ser considerado por alguns economistas de prol como sendo um capítulo estranho à Economia. SENior, por exemplo, que repelira o conceito demasiado estreito e materializado de produ- 
ção, não titubeava em proclamar que tôda a matéria referente ao consumo antes interessa à Moral, à Higiene ou à Ciência da Administração do que à Economia Política. A Economia, no sentido próprio dêste têrmo, deveria cuidar apenas da produção, da distribuição e da circulação das riquezas, confiando o problema do consumo aos cuidados normativos de uma política social norteada por juizos de valor ético ou sanitário.

O marxismo como ideologia de produção

Pois bem, foi nos quadros de uma economia fundamentalmente produtivista que se desferiu a crítica de socialismo científico, do socialismo marxista. Aqui é que desejo acentuar um ponto nem sempre posto em evidência pelos estudiosos da matéria. Qual foi a maior originalidade de KarL Marx, dentre as poucas ou muitas (a matéria é controvertida) que teve nesta matéria que estamos analisando? A originalidade genial de KarL MARx consistiu, a meu ver, em ter compreendido o anacronismo de uma política socialista fundada em meras reivindicações morais dos consumidores, postulando, ao contrário, um socialismo baseado na teoria da producão. A sua grande novidade para o mundo socialista foi, repito, ter posto o problema do socialismo em têrmos de produção, e não em têrmos de consumo. Na realidade, Karl Marx adaptava-se aos novos tempos para transformar-lhes a estrutura e o rítmo. Visto sob êsse prisma particular, poder-se-á dizer que o mentor do coletivismo foi um discípulo da Escola Clássica, heterodoxo, revolucionário, mas imbuído de seu produtivismo radical.

É conhecida a advertência de KarL Marx de que de quem olha a vida econômica capitalista através da circulação exterior das riquezas tem a impressão de uma igualdade entre dar e receber; mas quem penetra no laborató- 
rio secreto da produção verifica quantas razões há para as revoltas do homem que aliena a fôrça de seu trabalho, pois, diz Marx, o fim último da produção capitalista é "a apropriação e a capitalização da mais valia", com esquecimento das necessidades humanas. Surge, como se vê, a doutrina marxista como uma crítica à produção de tìpo capitalista. É estranho e até certo ponto paradoxal que a obra príncipe de KARL MARx não se chame "O Trabalho", mas sim "O capital" O capital é, na realidade, a grande personagem da dramaturgia marxista, mas, por de trás do capital, que se move como um frio Deus terreno, a devorar saturnicamente os próprios filhos, vislumbra-se o proletariado, o novo Deus que o profeta de Treves nos aponta, pronto a empunhar o facho da produtividade crescente, comprometida, a seu ver, de maneira inexorável, pelas esclerosadas e cada vez mais engurgitadas artérias do capitalismo centralizador e proletarizante.

Frize-se que, nessa ciclópica análise da produção capitalista, foi mérito de MARX não se ter deixado circunscrever por um conceito estritamente técnico de capital, compreendendo a necessidade de situar o problema na concreção e na totalidade do processo histórico, atitude esta que iria ter tão profunda repercussão no desenvolvimento da historiografia social e econômica.

Neste ponto não se lhe pode recusar originalidade. Muitas das teses marxistas podem ser filiadas aos economistas clássicos ou a estudiosos autônomos, como SisMoNDr, por exemplo, mas façamos abstração do problema tão delicado das filiações teóricas, para atentarmos mais ao índice de potenciação das idéias. Ora, uma das idéias potenciadas por KarL MARx é exatamente esta: a de que "o capital não é uma coisa, mas uma relação determinada de produção", e que, por conseguinte, o problema da produção transcende os lindes e as categorias do tecnicismo tradicional, para situar-se na totalidade das circunstâncias sociais e históricas. Esta é, segundo me 
parece, uma colocação metódica de grande valia, posteriormente aceita por estudiosos que não têm com KarL MarX outra relação que não seja a natural admiração que todo homem de pensamento dedica àquêles que suscitam idéias novas para o debate das contingências humanas. Produção, pois, não apenas como fato econômico, mas como expressão dos problemas humanos focalizados em sua totalidade orgânica.

Pena é que Marx tenha pago tributo tão elevado à mentalidade dominante em seu tempo, fazendo, de um lado, a crítica à produção de tipo capitalista, e, do outro, modelando a sua ideóloga política em têrmos eminentemente produtivistas, com desprêso da que parecia ser a sua preocupação inicial: a conexão técnico-científica entre o desenvolvimento da produção e o desenvolvimento do consumo.

Em verdade, por que Karl Marx se tinha na conta de "socialista científico"? Porque, penetrando nos meandros da produção capitalista e julgando descobrir-lhe os segredos, julgava poder inferir do seu processo dialético, marcado por crises sucessivas, a eclosão de uma crise final, irremediável, de estrutura, substituindo-se um sistema de produção, baseado na propriedade privada, por outro sistema fundado na "socialização dos meios de produção".

A visão do capitalismo que Marx nos apresenta é, dessarte, apocalíptica. Para êle o processo de produção de tipo capitalista está minado por uma contradição radical, que tentarei fixar em breves traços. A produção já está socializada, diz êle, visto como todos tomam parte nela. Tudo quanto é produzido nunca é o reflexo do esfôrço criador de um só, mas é, ao contrário, o ponto final de uma série de elos, de um rosário produtivo de elaborações anteriores, de sorte que onde quer que haja um produto aí se nos depara uma produção socializada. Em contraposição à produção socializada, como ato genético, persiste, todavia, aberrantemente, a propriedade 
particular cercada de tôdas as prerrogativas jurídico- políticas. Produção social em contraste com propriedade juridicamente individualizada, eis, no dizer de Marx, a fonte das crises inevitáveis. A produção capitalista, incapaz de vencer tal antagonismo, vive ao sabor das crises renovadas, provocando, de um lado, a concentração crescente dos capitais e, de outro, a proletarização crescente. Donde a luta de classes, o conflito social, cujo desfecho último é a queda da burguesia e a ascensão do proletariado para o advento de uma bemaventurada sociedade comunista, sem classes e sem oprimidos.

Pensava êle que sòmente graças à socialização dos meios de produção seria possível preservar o rítmo ascensional da economia, aquêle surto de produção que fôra o ideal dos mentores da Escola clássica. No fundo, portanto, mantinha-se fiel aos ideais de produtivismo da economia manchesteriana, embora pretendendo contraporse a seus objetivos: KarL MARx, cuja formação econômica se aperfeiçoou na Inglaterra, na meditação dos mestres do liberalismo econômico, dêles não se divorciou pelo menos num ponto: no que tange à crença de que o essencial è o aumento da produção, pois dêsse aumento haveria de resultar, automàticamente, o benefício geral de todos. Talvez não haja exagêro em conjeturar que MArX não teria sido socialista se não estivesse convencido da maior produtividade, do maior rendimento econômico oriundo da "socialização dos meios de produção" Não será êste o grande paradoxo do marxismo? A corrida soviética para a produção, a obsessão de atingir e superar incontinenti os índices da economia norte-americana, revela-nos que uma mudança radical se operou no plano dos instrumentos de ação, mas não no âmago das tendências, no espírito primordial das concepções econômicas. São dois "produtivismos" em conflito, ostentando duas técnicas distintas, abstração feita, é claro, de outros aspectos essenciais, de ordem moral ou política, ligados a êsse formidável con- 
traste de idéias e de recursos materiais, pois o presente trabalho está adstrito à problemática da produção.

Desejo esclarecer, desde logo, que esta concepção produtivista, quer do capitalismo, quer do marxismo, não podia deixar de prevalecer sôbre a acanhada visão de uma economia jungida passivamente aos limites de um mercado consumidor, cujas exigências ínfimas resultavam do número insignificante de indivíduos que, antes da era industrial, logravam ser efetivamente partícipes de melhores condições de vida.

Economia de consumo significava apenas economia rotineira, traduzindo-se em privilégios para alguns, e em miséria para a esmagadora maioria. Sob êsse ponto de vista, mister é reconhecer que os empreendedores capitalistas, não obstante os abusos iniciais que macularam a entrada da máquina a vapor no mundo dos negócios, dinamizaram a vida econômica, abrindo, em pouco tempo, novas possibilidades de participação vital às massas trabalhadoras, diminuindo a mortalidade infantil, aumentando o índice médio de vida, eliminando progressivamente as carestias e as epidemias devastadoras, com a inegável generalização de melhores "standards" de consumo.

Ter proclamado o caráter utópico de uma solução puramente distributivista, preferindo pôr o problema do socialismo em têrmos de prévio aumento de produção, foi o mérito de Marx. Forjado, porém, no clima naturalista do século xIx, aliou êle o otimismo ascensional da dialética hegeliana ao otimismo progressista dos economistas britânicos, fiel à tese da perfectibilidade crescente do homem com base na mera solução de seus problemas econômicos-vitais.

É aqui que surgem dúvidas e inquietações aterradoras do mundo contemporâneo, uma de cujos dramas, como acentua Lours Baudin, é o conflito entre a Técnica $e$ a Política. 


\section{III}

A economia normativa e a implicação entre produção e consumo

Hoje, em dia não subsiste mais a crença generalizada de que o problema por excelência do homem consista no aprimoramento dos meios de produção, ou no encontro de novos esquemas jurídico-políticos que os convertam em peças ou instrumentos exclusivos da organização estatal.

É inegável que o homem atual não acalenta a ilusão iluminista de que os progressos da ciência e da técnica bastem para promover o advento de uma nova era de paz e de confôrto. Reconhece-se, ao contrário, que a ciência tanto pode propiciar resultados positivos como negativos, pondo em risco a vida, à medida que nos entreabre condições de vida mais cômoda e fácil. Já foi dito, aliás, com desconsôlo, que, quanto mais avançamos, de conquista em conquista, no domínio progressivo da natureza, mais nos assalta o sentimento de nosso ser periclitante, escravizados cada vez mais os homens uns aos outros e às coisas.

Compreende-se que a ciência é um meio, um instrumento neutro de ação humana, e que o valor dela está na dependência do emprêgo ético dado aos recursos que o prodígio das descobertas e das invenções nos propicia. A questão torna-se, dêsse modo, mais complexa, pois o que no fundo de iôdas as perplexidades se percebe é o desejo de uma integração unitária, na qual a ciência, a produção e o consumo se articulem de maneira harmônica. em função das exigências e aspirações materiais e espirituais da espécie humana.

Postos, assim, os dados da questão, vê-se logo que seria absurdo querer retroceder à época de uma economia estática, ou de renúncias progressivas, bloqueadas as situações humanas, encerrado 'o ciclo de mobilidade dos quadros 
sociais, para imperar a previsão burocrática e fria entre o "quantum" da produção e o "quantum" do consumo.

Isto seria tão anacrônico como querer sustentar, num saudosismo manchesteriano, que melhor fôra deixar os processos econômicos entregues a si mesmos, pois, cada qual, cuidando de si, estaria implicitamente cuidando do próximo. . Quem alimentará ainda a crença no "equilíbrio automático dos egoismos"?

Por outro lado, bem poucos estarão absolutamente convencidos de que a felicidade geral será o resultado imanente de um crescendo de produtividade. No mundo conturbado em que vivemos fácil é reconhecer que as mais estonteantes revelações do saber científico têm servido mais para gerar inquietações do que para acobertar nossos espíritos com o manto desejado da tranquilidade e da paz.

Que seja necessário pensar em têrmos de "economia normativa" (note-se que evito a expressão "economia dirigida", apegada a uma concepção unilinear do problema), eis uma verdade que me parece deva ser considerada assente, dependendo de precisar-se com rigor o emprêgo da expressão: "economia normativa"

Sem antecipar algumas das conclusões desta palestra, podemos concluir do já exposto que as condições subjetivas e objetivas, assinaladas como pressupostos da economia prevalecentemente produtivista. sofreram uma alteração substancial.

Em primeiro lugar, ao otimismo anterior sucede, se não uma atitude pessimista, - que chega, às vêzes, a se converter em angústia e em ansiedade, como se estivéssemos na iminência de uma catástrofe irremediável, sucede pelo menos uma atitude mais precavida e prudente, apelando para a vigilância e a interferência criadora dos homens de govêrno, assim como dos próprios responsáveis pelo processo produtivo, a fim de que o fato econômico não se desenrole à margem de uma esclarecidá opção programática. 
Nasce dai uma confiança maior na capacidade diretora do homem, atribuindo-se-lhe o poder de alterar, em seu benefício, graças a providências fundadas em dados objetivos, o curso expontâneo da história. Atitude, por conseguinte, de um humanismo que se poderia denominar "de potência", bem distinto, por exemplo, dos propósitos humanísticos de um MARx, por demais algemado à sua tese sôbre os meios técnicos de produção como fator determinante de tôdas as "ideologias", o que equivale a dizer, também condicionador de elementos espirituais ou psicológicos, que, a meu ver, condicionam a economia, embora com ela se mantenham em estreito liame, em uma relação dialética de implicação e de polaridade.

Seria injusto recusar-se o significado humanístico da obra de KARL MARX, com o seu programa de emancipação dos homens "alienados" ao processo econômico de seu tempo, mas o humanismo marxista revela-se unilateral, fadado à auto-destruição, porque subordinado à teoria naturalista do progressivo govêrno das coisas, segundo leis imanentes no próprio desenrolar-se do fato econômico. o que é essencial, ao contrário, como condição da tarefa que se nos antolha, é um humanismo que, sem converter o homem num deus terreno pretencioso, também não o converta em mero participante, ora feliz, ora temeroso, de uma história, cujo roteiro não orienta, ou quando muito vislumbra nas obscuras profundezas da chamada infraestrutura econômica.

Razões há, além do mais, no plano objetivo, no plano extrínseco das coisas, para defender-se tal atitude de "humanismo de potência". A técnica de nossa época não é mais o instrumento teórico e mecânico incipiente que propulsionou as primeiras arremetidas capitalistas. A aliança da ciência com a produção, a que já fiz referência, não só transformou fìsicamente a face da terra, como implicou também em radicais alterações na problemática do trabalho. Vemos alargar-se, dia a dia, a esfera de participação criadora ou inteligente dos que produzem, não 
só por se exigir maior apuro técnico nas tarefas mais rudes, mas especialmente pelo crescente número de colaboradores de cunho intelectual. De modo geral, pode-se dizer que ocorre uma intelectualização crescente do trabalho manual, e que, ao mesmo tempo, vai crescendo, dia a dia, o índice de prevalência dos fatôres intelectivos no processo da produção.

Contrariando certas Cassandras, o progresso técnico não conduz, irremediàvelmente, ao automatismo dos atos produtivos, à despersonalização do trabalho, pelo divórcio cada vez mais pronunciado entre o produtor e a sua obra, estilhaçada e imperceptível no jôgo das tarefas distribuídas na produção anônima, em série. Se, de um lado, cresce o automatismo, de outro, o maior rendimento faculta maiores salários, compensa o trabalho com maior lazer, propiciando-lhe oportunidades para o livre empenho do espírito. É possivel, outrossim, que sobrevenha um entusiasmo novo, como resultado de um "trabalho de equipe", desde que se saiba criar a "participação comunitária" indispensável a que o operário-técnico e o empresário se sintam unidos em virtude da produção comum.

Se, como efetivamente procede, um dos problemas a resolver é o do trabalho com alegria, não é dito que não possa haver alegria no trabalho de grupo, quando haja autêntico sentido de participação, e desde que o valor objetivo da obra, contemplada no seu conjunto harmônico, empreste relêvo a cada ato singular. Nas grandes catedrais góticas não se encontram, freqüentemente, nomes de artífices ou de artistas; as individualidades criadoras se projetam na beleza institucional do todo. Sem ir a tais extremos da dedicação plena, não resta dúvida que condições psicológicas propícias lograrão restituir vibração humana à monotonia dos esforços ajustados ao rítmo transpessoal das máquinas. Eis aí como a situação psicosocial do operário, a consciência da totalidade da obra, tem importância decisiva para o problema moral e eugênico do trabalho. Nesta ordem de idéias, a iniciativa soviética de promover competições, com ressonância na rede dos 
interêsses nacionais, entre os vários centros de produção, usinas, emprêsas agrícolas, etc. confirma, mesmo no ambiente coletivista das igualdades prometidas, o alcance das teorias que, com penetrante senso das realidades humanas, mandam se atente aos fatôres de ordem psicológica no trato dos problemas de produção, na aparência apenas dependentes de aperfeiçoamentos nos maquinismos. Como bem observa Françors Perroux, o essencial é que cada operário possa ver o resultado de seu trabalho em sua utilização ulterior, assim como situá-lo no conjunto dos trabalhos executados pela emprêsa, o que se logrará obter graças a um plano de informações que esclareça o valor das tarefas discriminadas em equipes autônomas. $O$ que importa, em suma, é preservar o sentido de participação criadora no conjunto da obra, como uma exigência primordial da técnica de trabalho, fortalecida aquela participação por processos ou fórmulas sociais de salário capazes de superar a hostilidade que, por sentimento de injustiça, o trabalhador ainda conserve contra o próprio trabalho.

Dir-se-ia que se constitui entre o homem e a máquina uma trama de atos e reações. Não se olvide, contudo, que a máquina é sempre uma "coisa criada" pelo homem, algo, portanto, que cristaliza e conserva atos anteriores de pensamento e de vontade. Quando um dado maquinismo atua sôbre os homens, há apenas aparência de "atuação material": indo à raiz do fenômeno, são sempre homens (os inventores, os cientistas, os empresários, os realizadores técnicos da máquina) que, através da máquina, estão agindo uns sôbre os outros. É nesse fluxo de objetivacão do espírito em obras e bens culturais (entre os quais se situam os bens econômicos) e no refluxo dos bens culturais sôbre as subjetividades atuantes que se resolve o processo integrante da história.

É a falta de compreensão das máquinas como formas de objetivação humana que faz pensar numa civilização 
da máquina que não possa ser, como deve ser, uma civilização humanística.

A atenção devida a essa dimensão do problema previnir-nos-á contra certos desgarramentos operados em alguns setores do capitalismo no concernente à "racionalização", palavra que quase adquiriu fôrça mística, como se nela se ocultasse o talismã fadado a libertar a economia ocidental das crises periódicas que a atormentam.

Lembro-me, neste passo, de uma observação aguda de Guido de Ruggiero, salientando o contraste entre o ideal do homem grego, - que era o de racionalizar-se a si próprio - com o ideal do mundo atual, que é o de racionalizar as coisas e os serviços. Nessa transladação da ratio, do plano ético do homem para o plano quantificado dos utensílios e dos instrumentos de ação, é que se situa a conhecida frase equívoca de TAYLOR: "antes o homem era tudo, agora é o sistema"

Em lugar do homem o sistema, o que vale dizer: a grande maioria agindo sem qualquer poder de iniciativa, submersa na execução automática de algo pensado por outrem. À "alienação" material, referente à possível disparidade verificada na distribuição dos proveitos, soma-se outra "alienação" não menos grave, fruto da escravização mental do homem às medidas impostas pela máquina.

Note-se que falo da alienação do homem em geral, e não apenas na do operário, como se pensou em têrmos classistas. Já se obtemperou com acêrto que a escravização se estende também ao capitalista, ao chefe de emprêsa, que, podendo dispor da máquina, acaba por não mais dispor de seu tempo senão em função do bem possuído: passa êle a viver a vida compatível com as exigências esquemáticas dos instrumentos de produção. Numa inversão violenta de valores, a máquina como que modela o homem à sua imagem. Isto no campo individualista, ou de social democracia indefinida, porque, na esfera comunista, vai-se mais longe: a máquina modela o próprio 
Estado, que se converte em uma imensa usina desdobrada do Báltico até ao Pacífico.

Em lugar do homem o sistema. Não mais o homem com a sua capacidade inventiva, e os vôos da imaginação criadora, mas tudo pré-ordenado, planificado, programado, obedecendo a uma distribuição econômica de esforços para atingir-se o máximo resultado. Racionalização das coisas em lugar de racionalização do homem. Foi esta a bandeira que se levantou em certo momento da crise, e cuja valia deve ser reconhecida em seus devidos limites. Não há que falar em racionalização das coisas e dos processos produtivos esquecendo-se a dimensão fundamental do homem. O propósito primordial, em verdade, deve ser o da re-humanização da economia, quer perante a máquina, quer nas relações fundamentais entre produção e consumo.

Que é consumo? O consumo é o homem, pois todos, produtores e não produtores, velhos, moços e crianças, doentes e sadios, todos nós consumimos. Quando dizemos "o consumidor", indicamos, de certa forma, o homem na sua universalidade vital. Donde se há de concluir que a re-humanização da economia implicará na busca de maior adequação e funcionalidade às exigências fundamentais do consumidor.

Não pensem que, a esta altura dos acontecimentos históricos, esteja eu aqui a pregar uma economia anêmica ou de âmbito familiar, como se me parecesse melhor sofrear o "élan" da produção, que os homens de emprêsa deixassem de o ser. Ao contrário, penso que seria grande êrro estancar o impulso produtivo. É necessário, porém, que a produção não seja concebida como simples fato econômico, mas enquadrada na totalidade do processo social, isto é, disciplinada pelas exigências essenciais da existência humana, deixando, como ora acontece, de plasmar a sociedade inteira segundo os mais caprichosos e desproporcionados fluxos de inversão de capitais.

Esse é um dos pontos fundamentais a ser considerado em uma "economia normativa", ou seja, regida por normas 
èticas, segundo uma escala hierárquica de valores. Certos homens de emprêsa pensam que o que interessa é apenas produzir Primeiro produzir a mercadoria para depois se produzir o consumidor. A técnica de propaganda e todos os processos de aliciamento psicológico servem para modelar o homem segundo as exigências produtivas, mesmo quando se trata de suscitar no mercado consumidor verdadeiras subversões na ordem das preferências. $O$ supérfluo tende a deslocar o essencial, o ilusório a prevalecer sôbre o substancial, graças a mil formas de sedução. Já foi dito, aliás, por um crítico da economia burguesa, Arturo Labriola, que o capitalismo vive da "exploração do desperdício", do consumo falsamente orientado, do "gaspillage" na paz, recorrendo a inversões bélicas no desespêro agudo das crises.

Sei quanto é difícil discernir entre o essencial e o supérfluo no campo variegado da economia, existindo, como existem, quadros diversos e contrastantes de civilização, hábitos peculiares arraigados nas distintas órbitas de consumo, desniveis acentuados de padrões de vida, sem se esquecer a lição risonha de Voltatre: "o supérfluo, coisa tão necessária!"

Mas, convenhamos, por mais relativos e precários que sejam os limites do supérfluo, como não proclamar o desequilíbrio quando vemos televisões ostentadas em barracos de madeira, e objetos de luxo brilhando nos casebres dos desnutridos? Como não advertir o perigo dos gastos fáceis, da perda absoluta do sentido de poupança, que é a raiz e o estímulo das inversões produtivas e úteis?

\section{IV}

Educar para o consumo numa comunidade concreta de produtores

Relevem-me se aqui o educador aponta para uma questão que diz respeito à formação do homem para a 
vida econômica. Parece-me que se tem cuidado apenas de educar para a produção, esquecendo-se de educar para o consumo. Educar não apenas para produzir, mas educar também para consumir. Se não houver esta ação pedagógica correremos o risco de erigir uma civilização em barbárie, ou, por outras palavras, uma barbárie civilizada, tecnicizada, o homem produzindo cada vez mais sem saber o que fazer com a coisa produzida. A máquina a dominar os homens porque incapazes de abrangê-la e dominá-la numa compreensão espiritual superior. Educar para consumir será talvez o meio mais eficaz para por côbro a certos desgarramentos da produção, se é que não queremos a ingerência do Estado, num dirigismo de conseqüências funestas. Cabe, aliás, aos próprios homens de emprêsa compreender a gravidade desta conjuntura.

Se chego a uma destas conclusões, de que o problema da produção é também problema pedagógico, é porque estou convencido de que a técnica, por mais que gere bem estar material, não basta, por si só, pela simples oferta de bens úteis à vida, para criar condições propícias à felicidade do homem. O que queremos não é consumir, o que queremos não é produzir, o que queremos é produzir e consumir em um sentido de tranqüilidade e de plenitude. Sôbre tais bases é que podemos e devemos assentar uma economia humanística, regida por normas éticas, infensa a tôdas as explicações unilaterais, que deram realce $\mathrm{e}$ importância a um aspecto isolado do problema, desprezando os demais.

Devemos procurar atender ao homem total, isto é, em sua concretitude histórica e em sua circunstancialidade social, e não ao homem parcelado, dividido, fragmentado, atomizado, estilhaçado através de uma série de perspectivas que, isoladas, não possuem qualquer valor, qualquer significado.

Uma das características de uma economia èticamente normada é, no meu entender, a ausência de preconceitos 
metódicos, ou, por outras palavras, de soluções unilaterais, como, por exemplo, as que se extremam nestas duas asserções contraditórias: "a solução reside exclusivamente em tudo se confiar à iniciativa privada"; "a solução reside exclusivamente na socialização dos meios de produção".

Ora, se o que importa é uma economia a serviço do consumidor, para elevação plenária de seu "status" de "beneficiário das conquistas da ciência e da técnica", nada legitima o fanatismo de soluções que pareceram favoráveis quando outras eram as condições da vida produtiva, diversas as dimensões do saber científico e de suas aplicações. Frize-se, de passagem, que o repúdio que faço a tôdas as soluções unilaterais e reducionistas corresponde a uma das mais preciosas orientações da Filosofia contemporânea sôbre o acêrto do pluralismo metódico, discriminando dinâmicamente os meios de pesquisa em função das múltiplas esferas do real e da vida.

Socialização dos meios de produção? E por quê não? E por quê sempre assim? Socializar os meios de produção em determinadas circunstâncias e em certas oportunidades, sim; em outras circunstâncias e oportunidades não, por não ter sentido, por manifestar-se a medida antieconômica ou anti-humana. Tôda a vez que a mera exigência econômica da produção estrita entrar em conflito com outras dimensões fundamentais da vida humana, mister será examinar cada caso concreto, subordinando-se o econômico aos imperativos de ordem moral.

Iniciativa individual? E por quê não? Em certos países a iniciativa individual deve ser presservada e estimulada como condição primordial do desenvolvimento econômico. Refiro-me especialmente ao Brasil, cujos desníveis culturais e técnicos abrem perspectivas favoráveis ao bandeirismo econômico, tornando manifesto o equívoco da estatificação das fôrças produtivas em emprêsas públicas que, olvidando as regras elementares do cálculo hedo- 
nístıco, passam a agir ruinosamente como se fôssem instituições político-partidárias.

É claro que existem setores da vida econômica que postulam a ingerência do Estado, não só pelo risco que envolvem, como por se destinarem ao atendimento de necessidades sociais inadiáveis, que não possam aguardar condições compatíveis com a justa retribuição đ̉evida aos investimentos privados. Em casos dessa natureza, compreende-se e legitima-se a ação do Estado, quer diretamente, quer, de preferência, graças ao regime dos serviços públicos concedidos, subordinado a diretrizes de ordem moral e econômica, para que, de um lado, não ocorram os abusos do monopólio e, do outro, pela pressão das correntes demagógicas, não se parta a equação financeira essencial à continuidade e à expansão dos serviços reclamados pelo interêsse público.

0 mesmo critério plástico, aderente às peculiaridades de cada meio ambiente, deve ser seguido no que se refere ao outro gênero de providências administrativaș, isto é, ao sistema de fiscalização estatal das emprêsas, respeitando sempre o princípio fundamental que fixa a iniciativa privada como centro da ordem econômica em um Estado de Direito, tal como o proclama, aliás, o artigo 145 da nossa Carta Maior, visando a conciliação da liberdade de iniciativa com a valorização do trabalho humano, na medida da justiça social.

É, pois, de elogiar-se a orientação firmada no regime constitucional vigente que, sem eleger qualquer solução "a priori", abre um leque de possibilidades à intervenção do Estado, na ordem econômica, mediante prévia autorização legislativa e segundo uma gradação prudente que pode se desenvolver desde as formas de fiscalização e contrôle até às medidas radicais do monopólio, neste caso quando comprovada a incapacidade ou o desinterêsse das livres iniciativas, ou manifesta a ameaça de ruinosas absorções capitalistas. 
Perguntar-se-á se esta diversidade de critérios e de processos metódicos não importará em desequilíbrio na vida do Estado, gerando insegurança nas soluções de govêrno e apreensão no domínio dos negócios privados, sob o guante de imprevisto dirigismo burocrático. é preciso, porém, não olvidar que, nos têrmos de nossa Carta Magna, a intervenção terá sempre por limite os direitos fundamentais por ela assegurados. Não ignoro que têm havido abusos, notadamente em matéria de política cambial, onde a lei tem sido a grande ausente, mas é de se esperar que o Poder Judiciário venha a preservar cada vez mais a esfera das garantias individuais, mediante uma apreciação mais concreta e positiva dos fatos econômicos, passando do mero exame da legalidade formal ao exame corajoso da legalidade substancial dos atos administrativos.

Cabe, outrossim, ponderar que a multiplicidade dos meios de ação político-econômica só é incompatível com a unidade artificial e amorfa, fruto de idéias preconcebidas, sendo, ao contrário, condição para atingir-se a unidade social orgânica, caracterizada pela composição de elementos distintos mas complementares. A história tem horror à simetria, desfazendo, como castelos de cartas, os planos tendentes a subordinar a soluções monocórdicas os fatôres mutáveis le complexos da vida econômica. Até hoje não se conseguiu provar, por exemplo, que a socialização dos meios de produção redunde sempre no incremento das riquezas ou, ao contrário, que seja incompatível com o progresso das ciências, que se tem mostrado, aliás, indiferente às estruturas políticas, acomodando-se a tôdas...

O sentido de totalidade e de concreção, marcante na ação dos verdadeiros estadistas, previne-nos, assim, contra algumas orientações singelas que, pretendem introduzir reformas sociais, por simples impulsos éticos ou religiosos, com olvido dos limites ditados pela ciência econômica, ou, no extremo oposto, olvidam valores éticos e religiosos para subordinar a organização da sociedade a puros impe- 
rativos de produtividade, como se aos não economistas só coubesse, consoante sugere Ludwig von Mises, dar conselhos aos consumidores para a aquisição de hábitos morigerados e melhor uso dos bens que o capitalismo lhes enseja.

É mister, pois, se reconheça a legitimidade dos pontos de vista do economista e do sociólogo, do moralista e do psicólogo, do político e do jurista, de quantos cuidam das complexas ciências do homem, quando em jôgo os problemas humanos envolvidos na temática da produção.

Muitos fracassos na política econômica nacional, por exemplo, têm resultado do esquecimento da interpenetração dos fatôres atuantes no meio social. Reformas pomposas se tentam inùtilmente nas altas esferas burocráticas, quando o povo é mantido às escuras quanto aos escopos do govêrno, nem se cuida do clima psicológico indispensável a uma real participação criadora por parte daqueles cujos interêsses estejam envolvidos nas providências programadas. Acaba-se na ciranda das portarias e dos decretos, que as classes produtoras recebem prevenidas, e os demais com pasmosa indiferença. Sem exemplos de austeridade e de continuidade de propósitos, sem o sentimento que deve animar os que trabalham quando se sabem participes de uma comunidade concreta, como será possível o estímulo para a poupança, como condenar-se a fuga das aplicações parasitárias ou de gôzo? Como esperar-se a preferência por investimentos de caráter realmente produtivo?

Reconheçamos: em tais casos, o que triunfa é a demagogia alçando o estandarte rôto da distribuição da miséria, estancadas inexoràvelmente as fontes produtivas, com o sacrifício final dos consumidores.

Cuidemos, pois, da produção nacional, mas no quadro geral de tôdas as nossas circunstâncias, tendo em vista as necessidades e as contingências de um País que, como qualquer outro, está sujeito aos influxos da economia mundial, mas, que, como País subdesenvolvido, mais pa- 
dece no mercado internacional as conseqüências trágicas de seu baixo índice de produtividade humana e de sua incipiente estrutura técnica, tanto industrial como agrícola. As gritantes diferenças de nossas áreas de cultura; os profundos desniveis de rendimento que entre nós existem; a precária e intermitente adequação entre a política do crédito e a dos investimentos; a falta de correspondência entre o aumento crescente dos salários e do nível de vida e o paralelo e necessário acréscimo da produção "per capita"; a carência significativa do hábito de poupança, que no fundo é uma forma indireta de investimento; a permanente sensação de aventura que se liga ao jôgo desconcertante dos valores monetários, agravando tendências já bem nossas para o imediatismo e a fruição fácil; a economia comprometida por processos técnicos rotineiros ligados a problemas essenciais de estrutura, que se não querem afrontar no âmbito da indústria, do comércio e da agricultura; e, por fim, a crise psicológica, a aguda descrença que se avoluma, tudo está a demonstrar que, se é verdade para todos, para nós é de uma urgência alarmante a consideração integral e unitária dos problemas da produção nos quadros de uma comunidade concreta.

\section{V}

\section{A produção, problema existencial}

Já é tempo de concluir, pedindo me seja relevada a ligeira referência às conjunturas da economia nacional, quando meu propósito era apenas o de focalizar aspectos da produção na ideologia contemporânea. Quando, porém, as teses abstratas são trazidas ao plano de nossos interêsses, tornam-se mais vivas e palpáveis, como se adquirissem a corporeidade dos que produzem e consomem. 
Julgo dispensável oferecer conclusões, no sentido rigoroso do têrmo. Se elas já não brotam expontâneamente da exposição feita, mais valerão as perguntas formuladas, como convite à meditação pessoal.

Um ponto, porém, desejo acentuar: é quanto a necessidade de entender-se a produção de maneira funcional e dinâmica, como problema existencial que é, e de tal relêvo que deve ser posto no âmago do conflito entre a Técnica e a Política, pois, como adverte Baudin e me parece certo, "o consumo comanda (talvez fôsse melhor dizer: "deve comandar", pondero eu) a produção em quantidade, em qualidade e em estrutura".

É inegável que as crescentes conquistas da ciência e da técnica asseguram e tendem a assegurar a um número cada vez maior de sêres humanos um volume cada vez maior de bens de vida, de confôrto físico ou material. É essencial, todavia, que não se cuide apenas dos bens materiais. esquecendo-se perigosamente os valores espirituais, ou, de maneira mais específica, as graves questões de ordem psicológica e moral suscitadas pelo impacto da ciência e da técnica sôbre a sociedade contemporânea.

Ante a desproporção existente entre o progresso atingido pelas ciências positivas e a reduzida participação de grande parte das populações do globo nos benefícios gerais da civilização, pode-se dizer que tôdas as equações politicas fundam-se nos dados da apontada relação entre recursos técnicos e meios de ação social.

Sustentam os comunistas, como vimos, que só serão possiveis a continuidade dos progressos técnico-científicos e a fruição generalizada de seus resultados, se houver socialização dos meios de produção, enquanto que, segundo os que querem preservar as liberdades fundamentais do homem, a técnica e a ciência encontram o seu "habitat" natural, sem desvio de sua destinação humanística, nos quadros democráticos, reconhecendo muitos a necessidade 
de retificações e de aperfeiçoamentos substanciais na estrutura da economia capitalista, que, em última análise, poderia ser caracterizada como sendo "o sistema de produção e de circulação das riquezas fundado prevalecentemente (os mais conservadores preferem dizer: "exclusivamente") na livre emprêsa".

Entre os dois polos do comunismo e do capitalismo desenvolve-se tôda uma gama de fórmulas intermédias, como a dos socialistas revisionistas, que divergem do primeiro tão sòmente quanto ao prazo ou ao rítmo das socializações julgadas indispensáveis à coletividade, ou as que, proclamando embora os benefícios da propriedade privada e da livre iniciativa, evitam, contudo, ou repudiam o têrmo "capitalismo" por julgá-lo demasiado comprometido por uma concepção de economismo triunfante, que erigira o capital em sujeito dominante da vida social, quando já agora o trabalho deve ser considerado o sujeito por excelência da economia.

Fazendo abstração de divergências, que, às vêzes, decorrem da escolha de certo ângulo ou perspectiva, comungando na substância da solução prática proposta, penso gue, no fundo, a questão radical é a concernente ao problema do homem, que deve ser focalizado na totalidade de suas funções e tarefas. Não cultivo a ilusão dos que pensam que o simples acréscimo de bens materiais tem como conseqüência o aperfeiçoamento correspondente do espírito, de sorte que a questão não poderá jamais se resumir na eleição do mais eficaz dentre os sistemas de produzir. Os valores espirituais devem ser cultivados por si mesmos, e não como superestrutura ou decorrência de prévio bem estar físico. São categorias que se condicionam reciprocamente, de maneira que cabe aos govêrnos e às elites cuidar, paralela e concomitantemente, das duas ordens de problemas, isto é. da melhoria das condições de vida, e do aperfeiçoamento psíquico e espiritual do homem, chamado a usufruir dos benefícios da ciência e da técnica. 
Eis aí como a produção se põe como um problema antropológico, no sentido inais amplo desta palavra, envolvendo a totalidade existencial do homem.

Não se trata apenas de uma formulação teórica, posta no plano axiológico, para indicar a preferência por uma política econômica de cunho humanístico, mas antes de uma verdade válida para tôdas as soluções possíveis. É claro, contudo, que quem toma plena consciência dessa verdade fundamental, sôbre a produção como problema existencial, passa a ter outra atitude, mais aberta e compreensiva, perante os problemas de produção e do consumo, vendo, segundo um complexo unitário de perspectivas, as relações fundamentais do trabalho, reconhecido como sujeito da economia, mas na totalidade complementar de sua tríplice expressão criadora, como trabalho do braço, do capital e da inteligência.

o problema da produção, por conseguinte, transcende os domínios do mero equipamento mecânico ou os processos técnicos de racionalização, para implicar a problemática da existência, a qual não pode ser senão co-existência, intersubjetividade, correlação funcional entre indivíduos e grupos no âmbito de uma comunidade nacional, que, embora situada no conjunto universal das Nações, só poderá participar da "communitas gentium", de maneira autêntica, se souber disciplinar as suas atividades individuais e grupalistas segundo valores comunitários, não para a absorção dos indivíduos e dos grupos, mas para a sua potenciação harmônica.

Nem será possível atingir o ideal de uma vida comunitária sem se cuidar da educação social do homem, quer como ente que produz, quer como ente que consome, e isto não in abstracto, mas in concreto, pelo reconhecimento de que existe uma correlação essencial entre o problema ético da civilização (os italianos diriam melhor: civiltà) e o problema político da estruturação do Estado: sob ambos os prismas, põe-se o problema primordial do valor 
da pessoa humana e de seu primado sôbre os instrumentos de ação social.

Sem a educação integral do homem, preparando-o convenientemente para o gôzo e o emprêgo superior dos bens postos à sua disposição, nos limites das necessidades superiores da co-existência, poderemos assistir a uma nova forma de barbárie, convertidos os instrumentos de vida em ameaça crescente aos valores fundamentais que se identificam com o próprio ser do homem. 